\title{
PENGEMBANGAN KELAS VIRTUAL DENGAN GNOMIO DALAM KECAKAPAN KOMUNIKASI MATEMATIS SISWA TOPIK TRANSFORMASI GEOMETRI
}

\author{
Resti Artiyani Pratiwi', Aan Hendrayana ${ }^{2}$, Ihsanudin ${ }^{3}$ \\ ${ }^{1,2,3}$ Universitas Sultan Ageng Tirtayasa, Jalan Raya Jakarta Km. 04 Pakupatan, Kota Serang, Banten \\ restiartiyani@gmail.com
}

\begin{abstract}
In the subject matter of geometry transformation there are concepts that need visualization. Therefore, it needs virtual learning to present material that is equipped with the illustrations of real objects. This research was aimed to develope virtual class with gnomio in communication skill mathematical student of geometry transformation topic, and to know feasibility of product developed. This research is a kind of research and development was adopted ADDIE development model. The result showed that the virtual classes developed meet the validity and practicality index $\geq 62.50 \%$. The result test of media validation was $83.80 \%$ and material validation was $90.38 \%$ with a very good category. The results of practicality tests by teacher and students of consecutive $100 \%$, and $85.14 \%$ with a very good category. Test of the effectiveness used normalized gain $(\mathrm{N}$ Gain) and paired sample t-test. The result analysis using N-gain meet the N-gain limitation $\geq 0.3$ of 0.32 with medium category and analysis using paired sample t-test obtained sig. (2-tailed) of 0.002. Based on the results of the assessment of validity, practicality, and effectiveness, the virtual classes with gnomio developed meet the criteria of valid, practical and effective.
\end{abstract}

Keyword: Virtual Class, Gnomio, Mathematic Communication Skills, Geometry Transformation

\begin{abstract}
Abstrak
Pada pokok bahasan topik transformasi geometri terdapat konsep yang membutuhkan visualisasi. Oleh karena itu, dibutuhkannya pembelajaran virtual guna menyajikan materi yang dilengkapi dengan ilustasi objek yang nyata. Penelitian ini bertujuan untuk mengembangkan produk kelas virtual dengan gnomio dalam kecakapan komunikasi matematis siswa topik transformasi geometri, dan mengetahui kelayakan produk yang dikembangkan. Jenis penelitian ini merupakan penelitian dan pengembangan yang mengadaptasi model pengembangan ADDIE. Hasil penelitian menunjukkan bahwa kelas virtual yang dikembangkan memenuhi indeks kevalidan dan kepraktisan $\geq 62.50 \%$. Hasil uji validasi media sebesar $83.80 \%$ dan validasi materi sebesar $90.38 \%$ dengan kategori sangat baik. Hasil uji kepraktisan oleh guru dan siswa berturut-turut sebesar $100 \%$ dan $85.14 \%$ dengan kategori sangat baik. Uji keefektifan menggunakan normalitas gain $(N$-gain $)$ dan paired sample t-test. Hasil analisis menggunakan $N$-gain memenuhi batasan $N$-gain $\geq 0.3$ yaitu sebesar 0.32 dengan kategori sedang dan analisis menggunakan paired sample t-test diperoleh sig. (2-tailed) sebesar 0.002. Dari hasil penilaian kevalidan, kepraktisan, dan keefektifan diperoleh bahwa kelas virtual dengan gnomio yang dikembangkan telah memenuhi kriteria valid, praktis, dan efektif.
\end{abstract}

Kata Kunci: Kelas Virtual, Gnomio, Kecakapan Komunikasi Matematis, Transformasi Geometri

\section{PENDAHULUAN}

Perkembangan ilmu pengetahuan dan teknologi (IPTEK) yang begitu pesat menjadi salah satu tantangan yang dihadapi oleh dunia Pendidikan, selain adanya perubahan pergeseran paradigma Pendidikan. IPTEK telah membawa perubahan serta pembaharuan yang pesat dalam kehidupan manusia. Perkembangan IPTEK, khususnya teknologi informasi dan komunikasi kian merajarela. Pengaruh dari berkembangnya bidang teknologi informasi dan komunikasi, timbul gagasan elearning. Elearning merupakan proses pembelajaran dengan memanfaatkan elektronik, seperti komputer. Pembelajaran berbasis komputer tidak dapat dipisahkan dengan tuntutan pembelajaran abad 21. Berdasarkan 21st Century Patrnership Learning Framework, penguasaan terhadap teknologi 
informasi dan komunikasi memiliki pengaruh yang besar dalam perolehan keterampilan lain yang diperlukan. Hal ini juga dikemukan oleh Trilling dan Fadel (Zubaidah, 2016:5), penguasaan terhadap keterampilan literasi ICT memungkinkan penguasaan terhadap keterampilan dan kompetensi lain yang diperlukan untuk keberhasilan kehidupan di abad ke-21.

Elearning meliputi pembelajaran jarak jauh, pembelajaran virtual, pembelajaran online, pembelajaran berbasis web, dan lain-lain. Penggunaan teknologi yang memanfaatkan ruang maya dan penyajiannya dibuat sedemikian rupa agar terlihat menyerupai objek nyata dikenal dengan pembelajaran secara virtual. Pembelajaran virtual merupakan pembelajaran yang memanfaatkan komputer sebagai media pembelajaran dengan menggunakan internet, intanet, atau jaringan komputer lain. Digunakannya media virtual ini dapat membuat pembelajaran menjadi lebih efektif. Hal ini sesuai dengan prinsip pembelajaran yang tercamtum dalam Standar Kompetensi Lulusan dan Standar isi, "Pemanfaatan teknologi informasi dan komunikasi digunakan untuk meningkatkan efisien dan efektivitas pembelajaran". Tidak hanya itu, Mya Poe juga mengemukakan bahwa pembelajaran online akan menjadikan siswa lebih aktif dan reflektif.

Salah satu bidang studi yang memegang peranan penting dalam pendidikan adalah matematika. Matematika merupakan salah satu pengetahuan dasar yang harus dimiliki dan diberikan kepada siswa di setiap jenjangnya, sejak Sekolah Dasar hingga Perguruan Tinggi. Tidak dapat dipungkiri, matematika memiliki peranan penting dalam perkembangan ilmu pengetahuan dan teknologi. Menurut Imam Subandi dalam Bangun (2016, h.2), dewasa ini perkembangan pesat di bidang teknologi informasi dan komunikasi dilandasi oleh perkembangan matematika di bidang bilangan, aljabar, maupun geometri.

Salah satu kecakapan yang harus dimiliki oleh siswa dalam pembelajaran geometri adalah kecakapan komunikasi. Perlunya kecakapan komunikasi dalam pembelajaran matematika terlihat dari pernyataan NCTM, kecakapan ini terdapat pada standar proses dalam Principles and Standars for Schools Mathematics. Kecakapan komunikasi matematis menjadi bagian yang cukup penting dalam pembelajaran matematika.

"Communication is an essential process in learning mathematics", Ontario Ministry of Education dalam Literacy and Numeracy Secretariat (2010:1). Pentingnya kecakapan komunikasi matematis juga tertera pada pernyataan Baroody dalam Ansari (2018:5) yang mengemukakan bahwa terdapat dua alasan mengapa komunikasi matematika penting. Pertama matematika tidak hanya sekedar alat bantu siswa untuk berfikir, menemukan pola, menyelesaikan masalah, dan menarik kesimpulan, tetapi matematika juga sebagai alat untuk mengkomunikasikan ide dan pikiran siswa dengan tepat, jelas, dan ringkas. Kedua, matematika merupakan aktivitas sosial dimana terlibatnya siswa dan guru dalam berinteraksi.

Media pembelajaran berbasis virtual merupakan salah satu upaya untuk menciptakan pembelajaran matematika yang berkualitas, khususnya kecakapan komunikasi matematis siswa pada materi transformasi geometri. Hal ini diacu oleh NCTM pada Principles and Standars for School 
Mathematics, bahwa "The six Principles address overarching themes: Equity, Curriculum, Teaching, Learning, Assessment, Technology". Prinsip-prinsip ini digunakan sebagai panduan untuk mengembangkan pembelajaran matematika sekolah yang berkualitas tinggi. Teknologi merupakan salah satu dari prinsip matematika yang sangat penting dalam pengajaran dan pembelajaran matematika serta dapat meningkatkan pembelajaran matematika siswa.

Pengembangan kelas virtual berbasis elearning telah dilakukan oleh beberapa peneliti terdahulu, diantaranya kelas virtual yang dikembangkan oleh Gunawan dan Stefani (2018). Produk Gunawan dan Stefani bertujuan untuk melihat efektivitas pembelajaran matematika dengan menggunakan kelas virtual berbantuan web. Pengembangan lainnya dilakukan oleh Sudin dan Flaviana (2018) yang mengembangkan kelas virtual yang dapat dilakukan dimana saja dan kapan saja, bahkan aplikasi yang dikembangkan dapat dibuka menggunakan handphone sehingga mempermudah siswa dalam belajar.

Pemanfaatan kelas virtual dapat mendukung kecakapan komunikasi matematis siswa. Siswa dapat mengkomunikasikan ide dan pemahaman matematisnya baik menggunakan simbol, gambar, dan kata-kata dengan menggunakan fitur yang telah disediakan. Pernyataan ini diperkuat oleh Nasrullah dan Baharman (2017) yang mengatakan bahwa penggunakan kelas virtual dapat meningkatkan kemampuan komunikasi matematis. Berdasarkan hasil penelitiannya, peningkatan kemampuan komunikasi matematis dilihat dari perubahan skor rata-rata pretest dan posttest. Selain itu adanya pengaruh positif yang ditimbulkan dari penggunaan kelas virtual berupa keinginanan yang kuat dan rasa ingin tahu dalam mempelajari matematika.

Ada beberapa aplikasi berbantuan web yang dapat dijadikan sebagai kelas virtual salah satunya adalah moodle. Moodle merupakan salah satu perangkat lunak yang menawarkan sistem belajar secara virtual. Dimana bahan ajar yang digunakan dalam bentuk web. Keuntungan dari moodle ini adalah sifatnya yang open source, yang berarti bahwa aplikasi gratis dan dapat dikembangkan sendiri oleh pemakai. Salah satu layanan hosting elearning yang ditawarkan gratis oleh moodle adalah gnomio. Pemanfaatan gnomio dapat melalui multiplatform dimana dapat melalui komputer maupun handphone. Pengguna gnomio dapat mengunjungi situs https://www.gnomio.com/. Gnomio tidak membutuhkan perpanjangan hosting serta tidak membatasi pengguna. Gnomio menyediakan fitur kelas online yang didalamnya terdapat bahan ajar, forum diskusi, penugasan, kuis, dan sebagainya. Bahan ajar yang akan dimasukkan berupa video pembelajaran, .pdf, power point, geogebra, dan lainlain.

Berdasarkan latar belakang di atas, peneliti ingin memanfaatkan jaringan komputer sebagai media pembelajaran yang dapat diakses kapan pun dan dimana pun dengan melakukan pengembangan kelas virtual dengan gnomio, khususnya materi transformasi geometri yang meliputi konsep dan pengaplikasian yang abstrak, sehingga kegiatan pembelajaran tidak terbatas pada penjelasan konsep semata. Melalui media pembelajaran yang dilakukan secara virtual ini, siswa diharapkan dapat mengkomunikasikan gagasan dengan simbol, tabel, atau diagram untuk menjelaskan masalah 
matematika. Melalui kelas virtual dengan menggunakan gnomio diharapkan diperoleh hasil valid, praktis, dan efektif dalam penggunaannya.

\section{METODE}

Penelitian ini menggunakan jenis penelitian dan pengembangan atau Research and Development. Penelitian dan pengembangan merupakan penelitian yang bertujuan untuk mengembangkan produk yang divalidasi oleh beberapa tim ahli dan selanjutnya diujicobakan. Model pengembangan yang digunakan dalam penelitian ini adalah model ADDIE yang terdiri atas lima tahap pengembangan, yaitu analysis, design, development, implementation, dan evaluation. Kelima langkah atau tahap pengembangan tersebut dilakukan secara berkelanjutan dan berkesinambungan. Sampel penelitian ini adalah peserta didik kelas XI IPA 1 SMAN 1 Pabuaran sebanyak 9 orang. Instrumen pengumpulan data terdiri dari angket validasi, angket respon siswa, dan tes kecakapan komunikasi matematis. Teknik analisis data berupa analisis kevalidan, analisis kepraktisan, dan analisis keefektifan.

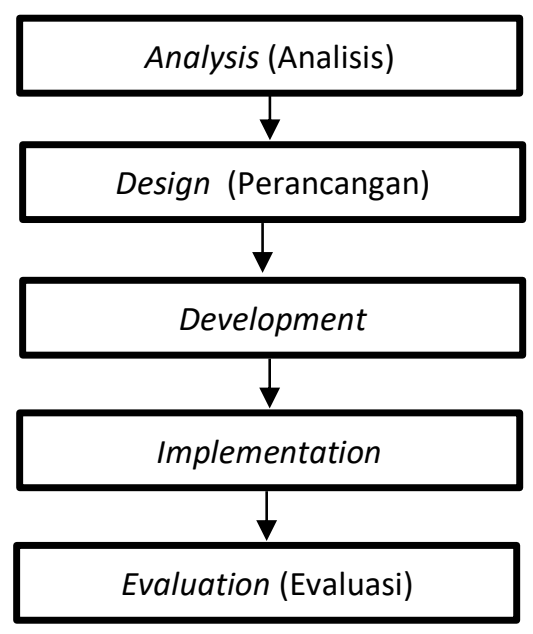

Gambar 1. Bagan ADDIE

\section{HASIL}

Pengembangan media kelas virtual pada topik transformasi geometri menggunakan model ADDIE yang terdiri atas lima tahap pengembangan, yaitu analysis, design, development, implementation, dan evaluation. Kelima langkah atau tahap pengembangan tersebut dilakukan secara berkelanjutan dan berkesinambungan.

\section{Analysis (Analisis)}

Analisis merupakan langkah pertama yang dilakukan oleh peneliti dalam tahap pengembangan media pembelajaran ini. Analisis ini dilakukan terhadap data yang diperoleh melalui kajian pustaka mengenai aspek-aspek dalam media pembelajaran, kurikulum, dan materi transformasi geometri. Dari hasil wawancara dengan guru matematika diketahui bahwa SMAN 1 Pabuaran menggunakan 
kurikulum 2013. Berdasarkan kurikulum 2013, peneliti memilih salah satu materi yang dipelajari oleh peserta didik kelas XI yaitu transformasi geometri. Materi transformasi geometri yang diajarkan harus sesuai dengan Kompetensi Dasar (KD) yaitu: (1) Menganalisis dan membandingkan transformasi dan komposisi transformasi dengan menggunakan matriks. (2) Menyelesaikan masalah yang berkaitan dengan matriks transformasi geometri (translasi, refleksi, dilatasi, dan rotasi).

\section{Design (Perancangan)}

Pada tahap ini, peneliti melakukan beberapa langkah untuk merancang kerangka isi media pembelajaran dan kerangka instrumen yang akan digunakan untuk menentukan kualifikasi media pembelajaran yang dikembangkan. Kerangka ini disesuaikan dengan analisis kurikulum, materi, dan media pembelajaran yang telah dilakukan. Perancangan kerangka isi media dimulai dari pemilihan format. Pemilihan format guna menggambarkan garis besar isi media secara umum yang dikembangkan. Hasil yang diperoleh berupa flowchart. Selanjutnya, peneliti mendesain media pembelajaran dengan membuat storyboard. Penyusunan instrumen yang akan digunakan untuk mengevaluasi kualitas media pembelajaran yang telah dibuat dan kecakapan komunikasi matematis peserta didik setelah menggunakan media pembelajaran

\section{Development (Pengembangan)}

Tahap pengembangan merupakan lanjutan dari tahap perancangan. Pada tahap ini, peneliti mengembangkan rancangan media pembelajaran yang telah dibuat. Pembuatan media pembelajaran berupa kelas virtual menggunakan www.gnomio.com. Berikut ini merupakan isi dari media pembelajaran yang dikembangkan.

\section{Bagian pembukaan}

Media kelas virtual yang dikembangkan dimulai dari bagian pembukaan. Bagian pembukaan terdiri dari menu masuk, timeline, dan menu utama. Tampilan menu masuk dapat dilihat pada Gambar 2.

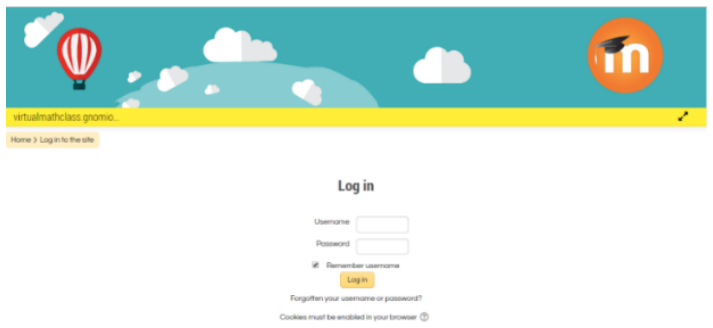

Gambar 2. Tampilan Bagian Pembuka

Pada bagian menu masuk ini, siswa diminta untuk mengisi username dan password yang telah diberikan kepada siswa untuk dapat mengikuti kelas virtual ini. Lalu, siswa menekan tombol login maka akan tampil menu utama pada kelas virtual ini. Tampilan menu utama dapat dilihat pada Gambar 3. 


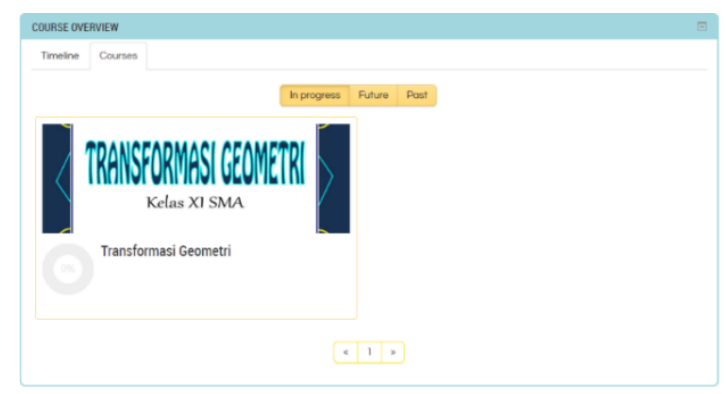

Gambar 3. Tampilan Menu Utama

Menu utama ini merupakan bagian pokok dalam media pembelajaran. Semua bagian-bagian media pembelajaran dapat diakses melalui menu utama ini. Bagian media tersebut terdiri dari petunjuk penggunaan, apersepsi, pretest, materi, eksplorasi, latihan, posttest dan respon siswa, serta profil.

Bagian petunjuk penggunaan

Tampilan petunjuk penggunaan terdiri dari penjelasan singkat tentang isi media pembelajaran dan penjelasan tentang petunjuk penggunaan media kelas virtual ini dapat dilihat pada Gambar 4.

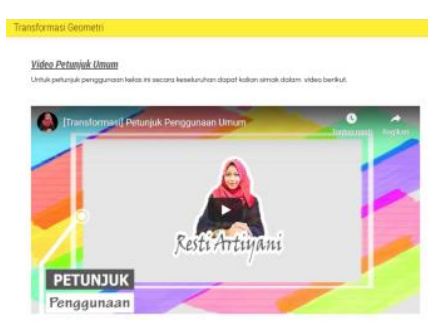

Gambar 4. Petunjuk Penggunaan

\section{Bagian apersepsi}

Tampilan bagian apersepsi dapat dilihat pada Gambar 5. Berikut tampilan apersepsi dalam penelitian ini

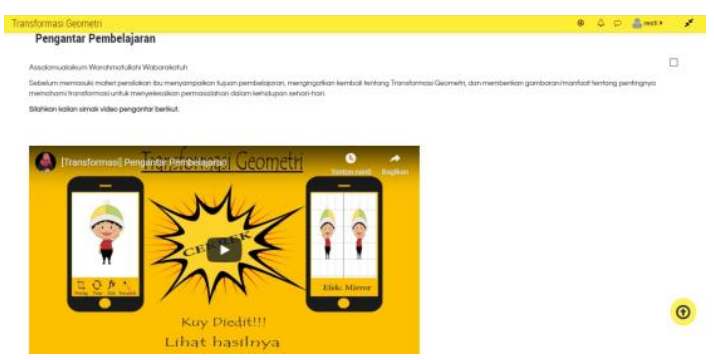

Gambar 5. Apersepsi

Bagian apersepsi ini berisi tujuan pembelajaran, mengingatkan kembali tentang transformasi geometri yang telah dipelajari waktu peserta didik duduk di bangku SMP, dan memberikan gambaran transformasi geometri dalam kehidupan sehari-hari. Apersepi yang digunakan berupa video pengantar pembelajaran.

\section{Bagian pretest}


Sebelum memasuki bagian materi, siswa harus mengerjakan pretest terlebih dahulu. Gambar 6 menunjukkan tampilan dari bagian pretest.

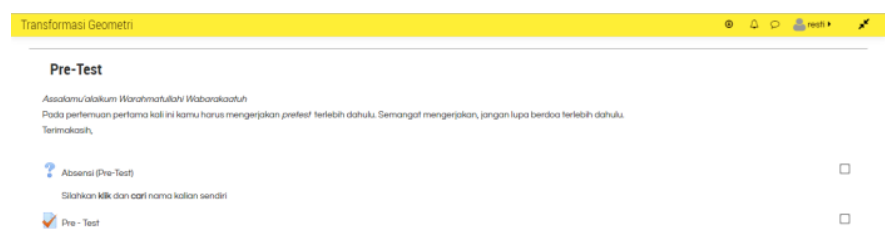

Gambar 6. Pretest

Pretest digunakan untuk mengetahui kemampuan awal siswa mengenai materi yang akan disampaikan. Soal pretest yang digunakan merupakan tes kecakapan komunikasi matematis.

Bagian materi

Bagian materi berisi tentang penjelasan mengenai materi transformasi beserta dengan contoh dalam kehidupan sehari-hari. Bagian materi terdiri dari video pembelajaran dan google slides. Tampilan materi berupa video ditunjukkan pada Gambar 7.

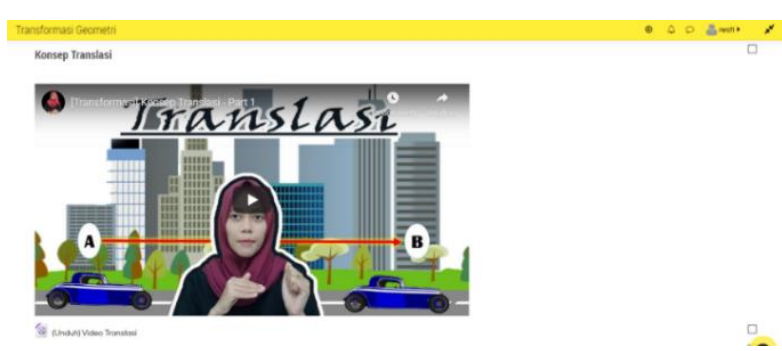

Gambar 7. Bagian materi translasi berupa video

Penjelasan materi berupa video pembelajaran. Dalam video pembelajaran ini berisi pengaplikasian yang digunakan dalam kehidupan sehari-hari, lalu dilanjutkan dengan pengertian dan jenis-jenisnya. Berikut tampilan materi berupa google slides ditunjukkan pada Gambar 8.

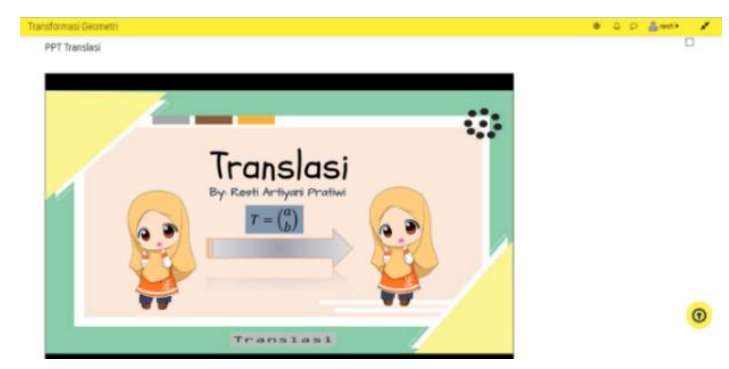

Gambar 8. Bagian materi translasi berupa google slides

Jenis serta contoh soalnya dapat dilihat pada google slides yang berada di bawah video pembelajaran. Sebelum dimasukkan ke dalam google slides, pembuatan contoh soal menggunakan program Microsoft Powerpoint 2010. Bagian materi baik video maupun google slidse dapat diunduh 
oleh siswa. Siswa hanya mengklik kata "UNDUH" di bawah bagian materi tersebut. Bagian eksplorasi

Kegiatan eksplorasi bertujuan agar siswa dapat meningkatkan kemampuan berimajinasi, mencoba-coba, dan memfasilitasi rasa ingin tahu para siswa. Setiap sub materi terdapat kegiatan bereksplorasi. Berikut salah satu contoh tampilan bagian eksplorasi pada materi translasi.

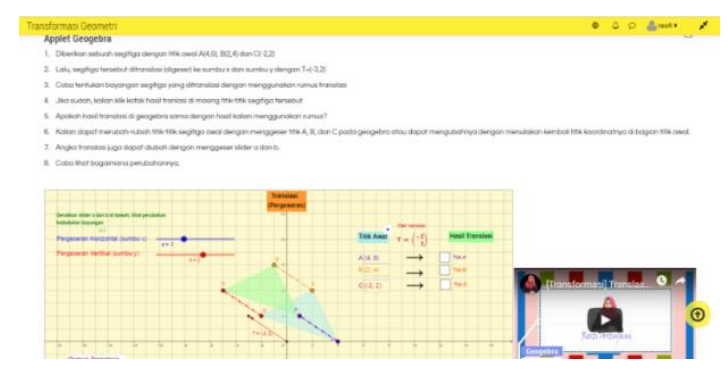

Gambar 9. Bagian ekplorasi materi translasi

Bagian ini berupa geogebra. Saat siswa mengaplikasikan geogebra, disamping itu terdapat video yang menuntun siswa dalam mengaplikasikan geogebra tersebut. Selain petunjuk penggunaan geogebra berupa video, siswa juga dapat melihat petunjuk penggunaannya secara tertulis yang berada di atas geogebra tersebut.

\section{Bagian latihan}

Setiap materi terdapat bagian latihan di dalamnya. Setiap latihan terdiri dari 5 soal. Gambar 10 menunjukkan tampilan latihan pada materi translasi.

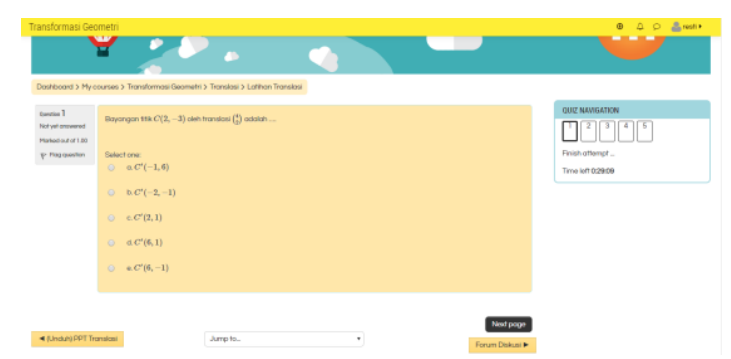

Gambar 10. Bagian latihan pada materi translasi

Bagian latihan berisi soal-soal untuk mengevaluasi pemahaman yang diperoleh oleh siswa. Soal-soal yang diberikan sesuai dengan kecakapan yang ingin dicapai yaitu kecakapan komunikasi matematis.

\section{Bagian forum diskusi}

Bagian forum diskusi terbagi menjadi dua, yaitu forum diskusi melalui chat dan forum diskusi secara langsung. Berikut forum diskusi dapat dilihat pada Gambar 11. 


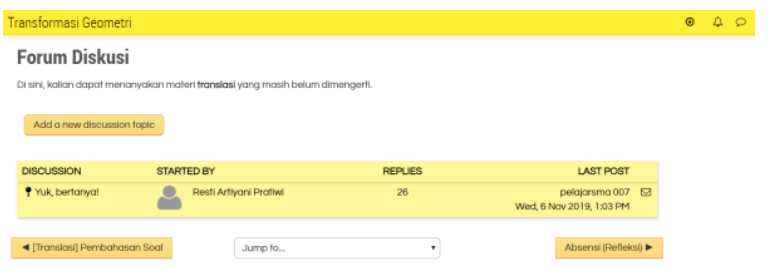

Gambar 11. Tampilan Forum Diskusi Melalui Chat

Bagian forum diskusi ini menggunakan fitur forum. Forum diskusi ini diadakan setiap pertemuan. Dengan menggunakan forum diskusi ini, siswa dapat menanyakan materi yang belum dimengerti melalui tulisan. Forum diskusi dapat berlangsung lama atau memiliki periode yang panjang. Selanjutnya, forum diskusi secara langsung. Berikut tampilan forum diskusi secara langsung dapat dilihat Gambar 12.

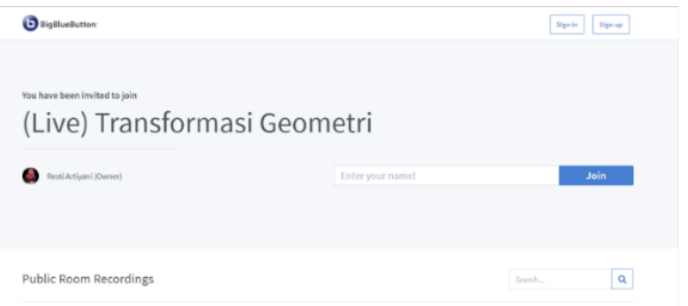

Gambar 12. Tampilan forum diskusi secara langsung

Forum diskusi ini diadakan menggunakan www.bigbluebutton.com. Dengan menggunakan forum diskusi seperti ini, siswa dapat bertanya lebih leluasa dengan guru. Gambar 12 merupakan tampilan masuk untuk mengikuti forum diskusi secara langsung dengan menggunakan bigbluebutton.com. Siswa hanya menuliskan namanya pada kolom kotak putih, lalu mengklik kata "Join" di sampingnya.

Bagian posttest dan respon siswa

Setelah siswa mempelajari semua materi dalam kelas virtual ini, siswa harus mengerjakan posttest dan respon siswa dalam penggunaan kelas virtual. Gambar 13 menujukkan tampilan dari bagian posttest.

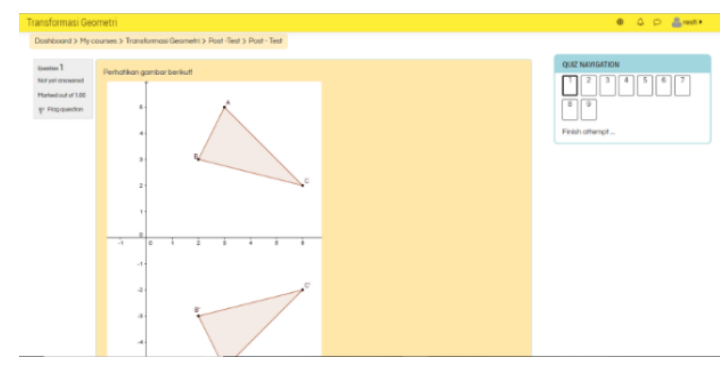

Gambar 13. Posttest 
Posttest digunakan untuk mengetahui kecakapan yang dicapai siswa setelah berakhirnya penyampaian pelajaran. Selanjtnya, bagian respon siswa. Gambar 14 menunjukkan tampilan dari bagian respon siswa.

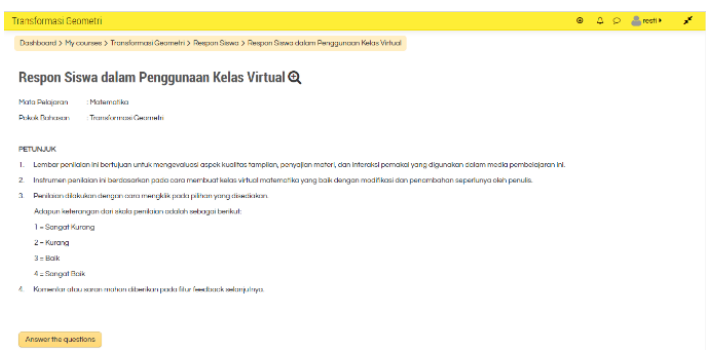

Gambar 14. Respon siswa

Respon siswa digunakan untuk mengetahui tanggapan siswa setelah mengikuti pembelajaran dengan menggunakan kelas virtual ini.

\section{Bagian profil pengembang}

Bagian profil berisi mengenai profil dari pengembang media pembelajaran. Gambar 15 menunjukkan tampilan bagian profil.

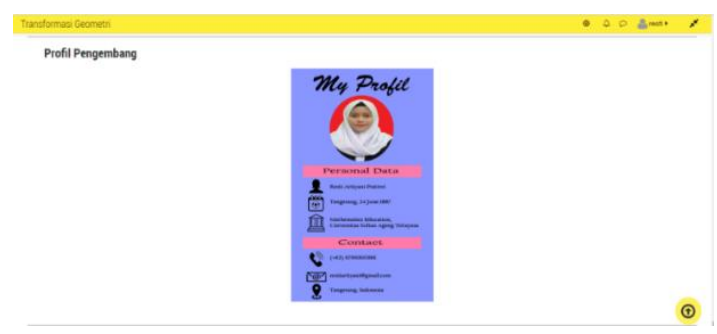

Gambar 15. Profil pengembang media pembelajaran

Profil terdiri dari data personal dan kontak. Data personal diantaranya nama, tempat tanggal lahir, dan jurusan serta kampus pendidikan dari pengembang media pembelajaran. Kontak yang ditulis terdiri dari nomor handphone, email, dan kota pengembang.

Hasil pengembangan media tersebut selanjutnya divalidasi oleh ahli materi, ahli media, dan guru matematika. Data yang diperoleh dari penilaian ahli kemudian dihitung berdasarkan kriteria dalam pengembangan media.

\section{Tabel 1.}

\section{Rekapitulasi Hasil Penilaian Ahli Media}

\begin{tabular}{ccccc}
\hline Aspek & Skor & Rata-rata & Persentase & Kategori \\
\hline Tampilan & 121 & 40.33 & $84.03 \%$ & Sangat baik \\
Pemograman & 60 & 20 & $83.33 \%$ & Sangat baik \\
\hline Total & 181 & & $83.80 \%$ & Sangat baik \\
\hline
\end{tabular}

Berdasarkan table 1, hasil penilaian ahli media untuk aspek tampilan dan pemograman setelah dihitung memperoleh persentase $83.80 \%$. Nilai ini kemudian dikonversi diperoleh bahwa penilaian 
kevalidan media kelas virtual berdasarkan penilaian dari ahli media termasuk dalam kategori sangat baik. Dengan demikian, kelas virtual dengan gnomio ini dinilai sangat valid sehingga dapat dinyatakan layak digunakan sebagai media pembelajaran.

\section{Tabel 2.}

Rekapitulasi Hasil Penilaian Ahli Materi

\begin{tabular}{ccccc}
\hline Aspek & Skor & Rata-rata & Persentase & Kategori \\
\hline Isi/Materi & 141 & 47 & $90.38 \%$ & Sangat baik \\
\hline
\end{tabular}

Adapun hasil penilaian ahli materi, media dinilai dari aspek kualitas isi/materi. Kelayakan kelas virtual degan gnomio setelah dihitung memperoleh persentase $90.38 \%$. Nilai ini kemudian dikonversi diperoleh bahwa penilaian kevalidan media kelas virtual berdasarkan penilaian dari ahli materi termasuk dalam kategori sangat baik. Dengan demikian, kelas virtual dengan gnomio ini dinilai sangat valid sehingga dapat dinyatakan layak digunakan sebagai media pembelajaran.

Selain ahli media dan ahli materi yang menilai kelayakan produk, penilaian juga dilakukan oleh guru matematika SMAN 1 Pabuaran. Penilaian yang dilakukan untuk mengetahui kepraktisan media pembelajaran yang dikembangkan.

\section{Tabel 3.}

Rekapitulasi Hasil Penilaian Praktisi

\begin{tabular}{ccccc}
\hline Aspek & Skor & Rata-rata & Persentase & Kategori \\
\hline Didaktik/Pengajaran & 24 & 4 & $100 \%$ & Sangat baik \\
kontruksi & 36 & 4 & $100 \%$ & Sangat baik \\
Teknis & 12 & 4 & $100 \%$ & Sangat baik \\
\hline Total & 72 & & $100 \%$ & Sangat baik \\
\hline
\end{tabular}

Berdasarkan hasil penilaian dari praktisi untuk aspek didaktik/pengajaran, kontruksi, dan teknis setelah dihitung memperoleh persentase 100\%. Nilai ini kemudian dikonversi diperoleh bahwa penilaian kepraktisan media kelas virtual termasuk dalam kategori sangat baik. Dengan demikian, kelas virtual dengan gnomio ini dinilai sangat praktis sehingga dapat dinyatakan layak digunakan sebagai media pembelajaran.

Penilaian media pembelajaran yang telah divalidasi oleh para ahli kemudian direvisi dengan mempertimbangkan masukan dan saran dari ahli dan tetap disesuaikan dengan tujuan awal penyusunan media pembelajaran. Setelah dilakukan revisi media kelas virtual, langkah selanjutnya adalah mengimplementasikan media kepada peserta didik.

\section{Implementation (Implementasi)}

Media pembelajaran berupa kelas virtual yang telah direvisi tersebut diujicobakan kepada peserta didik kelas XI SMAN 1 Pabuaran dengan tujuan untuk mengetahui kepraktisan dan keefektifan media pembelajaran yang dikembangkan. Jumlah peserta didik yang mengikuti uji coba 
adalah 9 orang, Jumlah pertemuan dilakukan sebanyak 5 kali. Uji coba dilakukan di laboratorium komputer SMAN 1 Pabuaran.

\section{Evaluation (Evaluasi)}

Setelah diujicoba, selanjutnya adalah tahap evaluasi. Tahap evaluasi merupakan tahap terakhir dalam pengembangan kelas virtual ini. Hasil dari uji coba dan evaluasi dari guru dan siswa digunakan sebagai acuan untuk memperbaiki media pembelajaran yang dikembangkan. Hal ini dikarenakan untuk mencapai tujuan yang telah ditetapkan. Peserta didik diminta mengisi angket respon siswa terhadap kelas virtual yang telah digunakan. Hasil rekapitulasi dari angket respon siswa kemudian dianalisis lalu dikonversi menjadi kategori kualitasnya.

Berdasarkan hasil penilaian dari peserta didik diperoleh bahwa tingkat pencapaian sebesar $85 \%$. Tingkat pencapaian tersebut kemudian dikonversi, hasil konversinya menunjukkan bahwa nilai tersebut termasuk dalam kategori sangat baik. Hal ini dapat ditarik kesimpulan bahwa media pembelajaran yang dikembangkan sangat layak digunakan baik dalam aspek tampilan, aspek penyajian materi, dan aspek interaksi pemakai.

Selain evaluasi terhadap media pembelajaran, dalam penelitian ini juga dilakukan pengukuran keefektifan media pembelajaran, dimana keefektifan media pembelajaran tersebut dilihat dari hasil pretest dan posttest. Pretest dan posttest dalam penelitian ini menggunakan tes kecakapan komunikasi matematis. Hasil tes kecakapan komunikasi matematis ini diukur dengan menggunakan normalitas gain (N-gain) dengan bantuan software Microsoft Excel 2010 dan dianalisis menggunakan uji paired sample t-test dengan bantuan software SPSS. Berikut hasil pengukuran $\mathrm{N}$-gain disajikan dalam Tabel 4 dan Tabel 5.

\section{Tabel 4.}

Hasil Pengukuran Normalitas Gain (N-gain)

\begin{tabular}{ccccl}
\hline P SMA & Pretest & Posttest & N-gain & Kriteria \\
\hline 001 & 22.22 & 44.44 & 0.29 & Rendah \\
003 & 0 & 33.33 & 0.33 & Sedang \\
004 & 11.11 & 44.44 & 0.38 & Sedang \\
005 & 0 & 55.56 & 0.56 & Sedang \\
006 & 33.33 & 22.22 & -0.17 & Rendah \\
007 & 22.22 & 44.44 & 0.29 & Rendah \\
008 & 11.11 & 33.33 & 0.25 & Rendah \\
009 & 33.33 & 66.67 & 0.50 & Sedang \\
010 & 11.11 & 44.44 & 0.37 & Sedang \\
\hline Jumlah & 144.44 & 388.88 & & \\
Rata-Rata & 16.05 & 43.21 & 0.32 & Sedang \\
\hline
\end{tabular}




\section{Tabel 5.}

Rekapitulasi Hasil Pengukuran Normalitas Gain (N-gain)

\begin{tabular}{llcc}
\hline & \multicolumn{2}{c}{ Normalitas Gain (N-gain) } & \\
\multicolumn{1}{c}{ Batasan } & Kategori & Jumlah & Persentase \\
\hline$g>0,7$ & Tinggi & 0 & 0 \\
$0,3 \leq g \leq 0,7$ & Sedang & 5 & $55.56 \%$ \\
$g<0,3$ & Rendah & 4 & $44.44 \%$ \\
\hline
\end{tabular}

Berdasarkan hasil normalitas gain pada tabel di atas, diketahui bahwa dari 9 responden yang mengikuti uji coba terdapat 5 peserta didik memiliki kecakapan komunikasi matematis dengan kategori sedang dan 4 peserta didik memiliki kecakapan komunikasi matematis dengan kategori rendah. Diperoleh rata-rata $\mathrm{N}$-gain sebesar 0,32 dengan kategori sedang. Selain diukur menggunakan normalitas gain, tes kecakapan komunikasi juga dianalisis dengan uji paired sample t-test. Uji paired sample t-test akan menunjukkan apakah sebelum dan sesudah penggunaan kelas virtual mengalami perubahan yang signifikan. Untuk melakukan uji paired sample t-test, data yang digunakan harus berdistribusi normal. Data berdistribusi normal mengartikan bahwa sampel yang digunakan dapat digeneralisasikan terhadap populasi. Data dalam penelitian ini berdistribusi normal. Tabel 6 menunjukkan bahwa data berdistribusi normal.

\section{Tabel 6.}

Hasil Pengujian Normalitas

\begin{tabular}{|c|c|r|r|r|r|r|}
\hline \multicolumn{1}{|c|}{ Kests of Normality } \\
\cline { 2 - 8 } & Statistic & df & Sig. & Statistic & df & Sig. \\
\hline Pretest & .208 & 9 & $.200^{*}$ & .899 & 9 & .248 \\
Posttest & .240 & 9 & .144 & .941 & 9 & .595 \\
\hline
\end{tabular}
a. Lilliefors Significance Correction
*. This is a lower bound of the true significance.

Menurut Dahlan dalam Rahman (2014:45), pemilihan uji normalitas didasarkan pada jumlah sampel yang akan diuji, jika sampel berjumlah $>50$ maka menggunakan uji Kolmogorov Smirnov, sedangkan jika sampel berjumlah $<50$ maka menggunakan uji Shapiro-Wilk. Dengan demikian, untuk pengujian normalitas dalam penelitian ini mengacu pada hasil output normalitas Shapiro-Wilk. Berdasarkan hasil pengujian normalitas, data tersebut menunjukkan bahwa nilai signifikansi dengan mengacu pada uji Shapiro-Wilk. untuk pretest sebesar 0.248 dan posttest sebesar 0.595. Sehingga berdasarkan uji normalitas Shapiro-Wilk nilai signifikansi lebih besar dari 0.05, maka data berdistribusi normal. Data yang diperoleh berdistribusi normal.

Hasil uji normalitas ini menentukan langkah selanjutnya, yaitu analisis statistik apa yang digunakan dalam penelitian dan pengembangan ini. Karena data yang diperoleh berdistribusi normal, maka analisis statistik yang digunakan adalah statistik parametrik. Statistik parametrik yang digunakan dalam penelitian dan pengembangan ini menggunakan uji paired sample t-test, dimana pengujian ini dilakukan karena data yang diuji berasal dari dua sampel dengan subjek yang sama dan mengalami dua perlakuan dan pengukuran yang berbeda. Menurut Sarwono (2009:134), uji t sampel 
berpasangan digunakan untuk membandingkan rata-rata dua variabel dalam satu kelompok. Pengujian paired sample t-test menggunakan bantuan program SPSS for windows versi 17.0. Hasil statistik deskriptif data hasil pretest dan posttest kecakapan komunikasi matematis dapat dilihat pada Tabel 7.

\section{Tabel 7.}

Statistik Deskriptif Data Hasil Pretest dan Posttest

Paired Samples Statistics

\begin{tabular}{|ll|c|r|r|r|}
\hline & & Mean & $N$ & Std. Deviation & $\begin{array}{c}\text { Std. Error } \\
\text { Mean }\end{array}$ \\
\hline Pair 1 & Pretest & 16.0478 & 9 & 12.55861 & 4.18620 \\
& Posttest & 43.2078 & 9 & 12.96512 & 4.32171 \\
\hline
\end{tabular}

Tabel paired sample statistics menunjukkan nilai deskriptif masing-masing variabel, dimana

a. Pretest memiliki nilai rata-rata 16.0478 dari 9 data. Sebaran data yang diperoleh adalah 12.55861 dengan standar error 4.18620.

b. Posttest memiliki nilai rata-rata 43.2078 dari 9 data. Sebaran data yang diperoleh adalah 12.96512 dengan standar error 4.32171 .

Berdasarkan data yang diperoleh di atas menunjukkan bahwa nilai rata-rata posttest lebih tinggi dari pada pretest, berarti secara deskriptif ada perbedaan rata-rata hasil pretest dan posttest. Selanjutnya, hasil uji paired sample t-test disajikan pada Tabel 8.

\section{Tabel 8.}

Hasil Uji Paired Sampel t-test

\begin{tabular}{|c|c|c|c|c|c|c|c|c|}
\hline \multicolumn{9}{|c|}{ Paired Samples Test } \\
\hline & \multicolumn{5}{|c|}{ Paired Differences } & \multirow[b]{3}{*}{$t$} & \multirow[b]{3}{*}{$d f$} & \multirow[b]{3}{*}{ Sig. (2-tailed) } \\
\hline & \multirow[b]{2}{*}{ Mean } & \multirow[b]{2}{*}{ Std. Deviation } & \multirow{2}{*}{$\begin{array}{l}\text { Std. Error } \\
\text { Mean }\end{array}$} & \multicolumn{2}{|c|}{$\begin{array}{l}\text { 95\% Confidence Interval of the } \\
\text { Difference }\end{array}$} & & & \\
\hline & & & & Lower & Upper & & & \\
\hline Pretest - Posttest & -27.16000 & 17.66622 & 5.88874 & -40.73946 & -13.58054 & -4.612 & 8 & .002 \\
\hline
\end{tabular}

Hasil tes kecakapan komunikasi matematis baik diukur dengan normalitas gain ( $N$-gain) maupun paired sample t-test menyimpulkan bahwa media pembelajaran yang dikembangkan efektif untuk digunakan pada pembelajaran matematika topik transformasi geometri.

\section{KESIMPULAN}

Berdasarkan hasil penelitian dan pembahasan, maka dapat disimpulkan bahwa kelayakan kelas virtual dengan gnomio dalam kecakapan komunikasi matematis berdasarkan penilaian kevalidan, kepraktisan, dan keefektifan sebagai berikut: (1) Hasil penilaian validitas oleh ahli media dan ahli materi menunjukkan bahwa media pembelajaran yang dikembangkan memenuhi indeks kevalidan $\geq$ 62.50\%. Hasil validasi media sebesar $83.80 \%$ dan validasi materi sebesar $90.38 \%$ dengan kategori sangat baik. Dengan demikian, media kelas virtual sangat valid digunakan dalam pembelajaran matematika. (2) Hasil penilaian kepraktisan media kelas virtual oleh guru matematika dan peserta didik kelas XI SMAN 1 Pabuaran menunjukkan bahwa media pembelajaran yang dikembangkan memenuhi indeks kepraktisan $\geq 62.50 \%$ secara berturut-turut sebesar $100 \%$ dan $85.14 \%$ dengan 
kategori sangat baik. Dengan demikian, media kelas virtual sangat praktis digunakan dalam pembelajaran matematika. (3) Hasil penilaian keefektifan dari hasil tes kecakapan komunikasi matematis dihitung menggunakan normalitas gain ( $N$-gain) dan uji paired sample t-test. Hasil perhitungan rata-rata $\mathrm{N}$-gain memenuhi batasan $\geq 0.3$ yaitu sebesar 0.32 dengan kategori sedang dan hasil perhitungan dengan uji paired sample t-test diperoleh sig (2-tailed) sebesar 0.002, dimana kurang dari 0.05 sehingga menunjukkan adanya pengaruh penggunaan kelas virtual dalam kecakapan komunikasi matematis. Hasil tes kecakapan komunikasi matematis baik diukur dengan normalitas gain ( $N$-gain) maupun paired sample t-test menyimpulkan bahwa media pembelajaran yang dikembangkan efektif untuk digunakan pada pembelajaran matematika.

\section{DAFTAR PUSTAKA}

Ansari, B. I. (2018). Komunikasi Matematik Strategi Berfikir dan Manajemen Belajar Konsep dan Aplikasi. Banda Aceh: Pena

Bangun, J. D. (2016). Pengembangan Media Pembelajaran Interaktif Matematika Siswa Kelas VII SMP Swasta Nurcahaya Medan. Program Pascasarjana. Medan: Universitas Negeri Medan.

Gunawan, F. I., \& Stefani, G.S. (2018). Pengembangan Kelas Virtual dengan Google Classroom dalam Keterampilan Pemecahan Masalah (Problem Solving) Topik Vektor Pada Siswa SMK Untuk Mendukung Pembelajaran. Prosiding Seminar Nasional Etnomatnesia.

Literacy and Numerary Secretariat. (2010). Communication in the Mathematics Classroom. The Capacity Building Series: Secretariat Special Edition 13.

Nasrullah \& Baharman. (2017). Pengaruh SMP Virtual Terhadap Kemampuan Penalaran Dan Komunikasi Siswa Dalam Pembelajaran Matematika. Makassar: Universitas Negeri Makassar, $662-666$.

NCTM. (2000). Principles and Standards for School Mathematics. United States of America: The National Council of Teachers of Mathematics, Inc.

Poe, M and MLA Stasssen. (2002). Teaching and Learning Online: Communication, Community, and Assessment, Journal A Handbook for UMass Faculty AMHERST: Center or Teaching Office of Academic Planning University of Massachusetts.

Rahman, F. A. (2014). Penerapan Model Pembelajaran Demonstrasi pada Mata Pelajaran Desain Grafis Untuk Meningkatkan Hasil Belajar Kognitif Siswa. Program Sarjana Pendidikan. Bandung: Universitas Pendidikan Indonesia.

Sarwono, J. (2009). Statitik itu Mudah: Panduan Lengkap untuk Belajar Komputasi Statistik Menggunakan SPSS 16. Yogyakarta: ANDI.

Sudin, V.V., \& Flaviana, M.T. (2018). Pengembangan Kelas Virtual Dengan LMS Kelase Untuk Pemahaman Konsep Siswa Dalam Materi Trigonometri Untuk Rumus Jumlah Dan Selisih Dua Sudut. Prosiding Seminar Nasional Etnomatnesia. 
Pengembangan Kelas Virtual Dengan Gnomio Dalam Kecakapan Komunikasi Matematis Siswa Topik Transformasi Geometri, Resti Artiyani Pratiwi, Aan Hendrayana, Ihsanudin

Zubaidah, S. (2016). Keterampilan Abad Ke-21: Keterampilan yang Diajarkan Melalui Pembelajaran.

Seminar Nasional Pendidikan dengan Tema Isu-Isu Strategis Pembelajaran MIPA Abad 21. Kalimantan Barat, 10 Desember. 